\title{
Macrophage activation syndrome due to systemic onset juvenile idiopathic arthritis in a case with liver transplantation
}

\author{
Kubra Ozturk ${ }^{1 *}$, Mehmet Baha Aytac ${ }^{2}$, Zelal Ekinci ${ }^{1}$ \\ From 21st European Pediatric Rheumatology (PReS) Congress \\ Belgrade, Serbia. 17-21 September 2014
}

\section{Introduction}

Macrophage activation syndrome (MAS) is a serious, potentially fatal complication of rheumatic diseases, which is seen most frequently in systemic onset juvenile idiopathic arthritis (soJIA).

\section{Objectives}

This case is reported to expose the difficulties of diagnosis and management of MAS due to soJIA in a patient with liver transplantation.

\section{Methods}

A 9-year-old girl (with a liver transplantation because of biliar hypoplasia from her father at the age of five years) presented with fever, rash and oligoarthiritis. An urgent tube thoracostomy was performed because of severe pleural effusion. She was transferred to the intensive care unit with the diagnosis of sepsis. On admission, the patient's white blood cells (WBC) $31600 / \mathrm{mm}^{3}$, platelets (plt) $40600 / \mathrm{mm}^{3}, \mathrm{C}$ reactive protein (CRP) $264 \mathrm{mg} / \mathrm{dl}$ and liver enzymes was normal. Because of persistent fever and pericardial effusion, bone marrow aspiration was performed and revealed hemophagocytosis. Intravenous methylprednisolone (IV) was administered at a dose of $30 \mathrm{mg} / \mathrm{kg} /$ day for three days. Fever was reported to subside and her treatment switched to oral methylprednisolone at a dose of $1.5 \mathrm{mg} / \mathrm{kg} /$ day. Maculopapular rash and pericardial effusion persisted. At that time the patient's hemoglobin (Hb) was $9.2 \mathrm{~g} / \mathrm{dL}$, WBC 40900/ $\mathrm{mm}^{3}$, plt $151000 / \mathrm{mm}^{3}$, erythrocyte sedimentation rate (ESR) $8 \mathrm{~mm} / \mathrm{h}$, CRP $8.26 \mathrm{mg} / \mathrm{dl}$, fibrinogen $3.7 \mathrm{~g} / \mathrm{l}$, alanine aminotransferase (ALT) $93 \mathrm{U} / \mathrm{l}$, aspartate

'Department of Pediatrics Rheumatology, Kocaeli Univertsity Faculty of Medicine, Kocaeli, Turkey

Full list of author information is available at the end of the article aminotransferase (AST) $69 \mathrm{U} / \mathrm{l}$. After four days, resistant high fever relapsed and dexamethasone, etoposide and IVIG added to her treatment. The dose of tacrolimus given for liver transplantation was increased to $3 \mathrm{mg} /$ day.

\section{Results}

When she was transferred to our clinic, physical examination was notable for temperature ranged from $40^{\circ} \mathrm{C}$ to above and maculopapular rash. Echocardiography revealed severe pericardial effusion. $\mathrm{Hb}$ was $6.1 \mathrm{~g} / \mathrm{dL}$, WBC $12600 / \mathrm{mm}^{3}$, plt $21800 / \mathrm{mm}^{3}$, ESR $4 \mathrm{~mm} / \mathrm{h}$, CRP $0.68 \mathrm{mg} / \mathrm{dl}$, fibrinogen $1.2 \mathrm{~g} / \mathrm{l}$, D-dimer $19.8 \mathrm{ug} / \mathrm{ml}$, ferritin $57798 \mathrm{ng} / \mathrm{ml}$, ALT $152 \mathrm{U} / \mathrm{l}$, AST $387 \mathrm{U} / \mathrm{l}$. Natural killer (NK) cells were found $1.2 \%$ (normal range 5-23\%). Tacrolimus level was severely toxic $(>30 \mathrm{ng} / \mathrm{ml}$ ) so treatment withdrawn. IV methylprednisolone was administered at a dose of $30 \mathrm{mg} / \mathrm{kg} /$ day for three days and switched to prednisolon $2 \mathrm{mg} / \mathrm{kg} /$ day. After the tacrolimus level decreased to $5 \mathrm{ng} / \mathrm{ml}$, cyclosporine $5 \mathrm{mg} / \mathrm{kg}$ was added. During that time Hb was $9.55 \mathrm{~g} / \mathrm{dL}$, WBC $5220 / \mathrm{mm}^{3}$, plt $21800 / \mathrm{mm}^{3}$, ESR $2 \mathrm{~mm} / \mathrm{h}$, CRP $0.13 \mathrm{mg} / \mathrm{dl}$, fibrinogen $1.9 \mathrm{~g} / \mathrm{l}$, D-dimer mmax. She was developed headache and dizziness. Because suspicion of central nervous system involment, anti thymocyte globulin (ATG) was administered. MRI which was reported as normal, could be performed the next day. ATG therapy continued because of persisting laboratory findings of MAS. In the fifth day of ATG therapy Hb was $9.41 \mathrm{~g} / \mathrm{dL}$, WBC $22000 / \mathrm{mm}^{3}$, plt $117000 / \mathrm{mm}^{3}$, ESR $2 \mathrm{~mm} / \mathrm{h}$, CRP $0.36 \mathrm{mg} / \mathrm{dl}$, fibrinogen $1.1 \mathrm{~g} / \mathrm{l}$, D-dimer $1.1 \mathrm{ug} / \mathrm{ml}$, ferritin $1381 \mathrm{ng} / \mathrm{ml}$. Anakinra $(1 \mathrm{mg} / \mathrm{kg} /$ day) was obtained and added to therapy. After -45- days follow up, she was discharged with prednisolon, cyclosporine and anakinra. 


\section{Conclusion}

MAS due to soJIA in a liver transplant patient; although diagnosed in the early phase of the disease, revealed difficulties in the management. Treatment with drugs proposed for hemophagocytic lymphohistiocytosis and increased dosage of tacrolimus did not sustained remission. The patient improved with cyclosporine and ATG. It is emphasized that MAS due to soJIA should be treated urgently with appropriate drugs.

\section{Disclosure of interest}

None declared.

\section{Authors' details}

${ }^{1}$ Department of Pediatrics Rheumatology, Kocaeli Univertsity Faculty of Medicine, Kocaeli, Turkey. ${ }^{2}$ Department of Pediatric Nephrology, Kocaeli Univertsity Faculty of Medicine, Kocaeli, Turkey.

Published: 17 September 2014

doi:10.1186/1546-0096-12-S1-P223

Cite this article as: Ozturk et al:: Macrophage activation syndrome due to systemic onset juvenile idiopathic arthritis in a case with liver transplantation. Pediatric Rheumatology 2014 12(Suppl 1):P223.

Submit your next manuscript to BioMed Central and take full advantage of:

- Convenient online submission

- Thorough peer review

- No space constraints or color figure charges

- Immediate publication on acceptance

- Inclusion in PubMed, CAS, Scopus and Google Scholar

- Research which is freely available for redistribution

Submit your manuscript at www.biomedcentral.com/submit 